\title{
Performance evaluation of New Zealand white rabbits fed Alchornea cordifolia leaf meal as replacement for soya bean meal
}

\author{
Philip Cheriose Nzien Alikwe, Elijah Ige Ohimain 2, *, Amos Ebiowei Kester ${ }^{1}$ \\ ${ }^{1}$ Biochemistry/Biotechnology Research Unit, Animal Science Department, Niger Delta University, Wilberforce Island, Bayelsa State \\ ${ }^{2}$ Agricultural and Veterinary Microbiology Research Unit, Biological Sciences Department, Niger Delta University, Wilberforce Island, \\ Bayelsa State
}

\section{Email address:}

eohimain@yahoo.com (E. I. Ohimain)

\section{To cite this article:}

Philip Cheriose Nzien Alikwe, Elijah Ige Ohimain, Amos Ebiowei Kester. Performance Evaluation of New Zealand White Rabbits Fed Alchornea cordifolia Leaf Meal as Replacement for Soya Bean Meal. American Journal of Agriculture and Forestry. Vol. 2, No. 2, 2014, pp. 51-54. doi: 10.11648/j.ajaf.20140202.16

\begin{abstract}
The Twenty-four weaned rabbits were fed graded levels of Alchornea cordifolia leaf meal (ACLM) at different inclusion levels in the diet. A control (0\%ACLM) and three other diets containing different levels of ACLM ( $5 \%, 10 \%$ and $15 \%$ ) as partial replacement for soya bean meal in the diet were fed for six weeks with the aim of evaluating the effects of ACLM on the growth performance and carcass characteristics of the rabbits. The study revealed a decrease in the growth rate with the highest level of inclusion i.e treatment D (15\%ACLM). The highest mean weight gain of $1.36 \pm 0.04 \mathrm{~kg}$ and feed intake of $131.94 \pm 7 \mathrm{~g}$ were recorded in treatment C (10\% ACLM inclusion in the diet) and the lowest mean weight gain of $1.14 \pm 0.04 \mathrm{~kg}$ was recorded in the treatment $\mathrm{A}(0 \% \mathrm{ACLM})$ and the lowest feed intake of $94.44 \pm 10 \mathrm{~g}$ was recorded in the treatment D. There was no significant difference $(\mathrm{P}>0.05)$ in feed conversion ratio (FCR) across the treatment groups. Carcass characteristics showed that live weight of rabbits fed 15\% ACLM diet was lower $(\mathrm{P}<0.05)$ than other experimental diets with lower percentage of ACLM which implies that 15\% ACLM diet possibly depressed the final weight of the experimental rabbits. This could be attributed to the higher percentage of the anti-nutritional factors in ACLM in treatment $\mathrm{D}$ which has been implicated for reduced weight gain. This study concluded that the use of ACLM may be recommended as protein source for rabbits but at $5-10 \%$ inclusion levels.
\end{abstract}

Keywords: Alchornea Cordifolia, Leafmeal, Soyabean, Rabbits, Supplements

\section{Introduction}

Like many developing countries Nigeria has for long been plagued with the problem of worsening situation of inadequate consumption of animal protein. Small scale rabbit production has been advocated as a viable income generating activity [1], which emerged as low cost answer to food insecurity among rural communities within the Country.

A panacea for the protein shortage is to target prolific livestock species with short reproductive cycle, high fecundity but also with high $(21 \%)$ crude protein and low $(5.40 \%)$ crude fat content in its meat [1]. The crude fat in rabbit meat is lower ( $8 \%$ ) when compared with beef $(35 \%)$, mutton (31\%), pork (29.5\%) and chicken (12\%) [3]. When compared with meat from other species, the fat in rabbit meat contains less stearic and oleic acids but a high proportion of the essential poly-unsaturated fatty acids such as linoleic[5]. Dandu et. al [6] reported that nonconventional feedstuff (NCF) offer the best alternative for the reduction in feed cost which ultimately leads to reduction in the prize of meat and other animal products. However, for this non-conventional feed-stuff to meet the need of reducing cost of production they must be available all year round and should be easy to procure and process when needed. Non-conventional feed-stuff may be of animals, plants or mineral origin. Alchornea cordifolia is one of the recently discovered plants used as performance enhancers in livestock and poultry industry [7]. The root and bark is used as stimulating intoxicant and aphrodisiac by the people of Congo in Africa Oliver [8]. After drying it is ground to a fine powder, and is mixed either with food or macerated for several days in palm wine and consumed to 
produce energy for tribal festivities and in warfare. It is said to produce a state of intense excitement followed by a deep and sometimes fatal depression [9]. In Nigeria, goats and sheep browse on its leaves. Its root and bark have $0.03-0.26 \%$ of total alkaloids while the leaves contain $10 \%$ of tannins (alkaloids) [9]. Wekle and Njoku [7] reported the effect of Alchornea cordifolia on weight gain and organ size in broilers and observed no significant effect on the overall weight gain but interestingly discovered its hypo tropic effects on the gonads which may lead to increase in testosterone production. They also discovered atrophy of the ovary of the females which may lead to the suppression of oestrogen production and related hormones and thus precipitate masculinity and reproductive impotency. The present study was therefore designed to determine the performance and carcass characteristics of rabbits fed Alchornea cordifolia leaf meal as partial replacement for soya bean meal.

\section{Materials and Methods}

\section{Processing of Alchornea Leaf:}

Fresh leaves of $A$. cordifolia were harvested from within the Campus of Niger Delta University, Wilberforce Island, Bayelsa State, Nigeria. The leaves were chopped and airdried for two weeks and milled into powder with grinding machine, then sieved and bagged in polythene bags and stored until needed. Samples of the powder (ACLM) were sent to the Biochemistry Laboratory of the Institute of Agriculture, Research and Training, Ibadan, Oyo State Nigeria for further analysis

\section{Experimental Diets:}

Four experimental diets were formulated. All the experimental diets were fed as a meal, and all major ingredients were ground in a hammer mill and mixed manually. In the experimental diets: 5, 10 and 15\% ACLM were added in partial replacement of soya bean meal (Table 1) as a protein feed-stuff.

Table 1. Ingredients composition of the Diets

\begin{tabular}{ccccc}
\hline Ingredients & \multicolumn{4}{c}{ Dietary levels of ACLM\% } \\
& 0.0 & 5.0 & 10.0 & 15.0 \\
\hline Maize & 43.0 & 43.0 & 43.0 & 43.0 \\
Soya bean meal & 17.0 & 12.0 & 7.0 & 2.0 \\
ACLM & 0.0 & 5.0 & 10.0 & 15.0 \\
Palm kernel meal & 12.0 & 12.0 & 12.0 & 12.0 \\
Wheat offal & 15.0 & 15.0 & 15.0 & 15.0 \\
Crayfish meal & 3.0 & 3.0 & 3.0 & 3.0 \\
Bone meal & 7.0 & 7.0 & 7.0 & 7.0 \\
Oyster shell & 2.0 & 2.0 & 2.0 & 2.0 \\
Salt & 0.50 & 0.50 & 0.50 & 0.50 \\
Premix & 0.50 & 0.50 & 0.50 & 0.50 \\
Total & 100 & 100 & 100 & 100 \\
Calculated crude & 18.0 & 16.7 & 15.4 & 14.1 \\
protein & 18.0 &
\end{tabular}

Experimental Design

Twenty-four 5-6 weeks old rabbits of mixed breeds comprising twelve (12) males and twelve (12) females with an initial average weight of $960 \mathrm{~g}$ were used for this study. The rabbits were housed in hutches with wire-mesh cages. Two hutches were used for this study with each hutch having six compartments (cages). The twelve cages were made to sit in a square wire-mesh base for easy cleaning. The rabbits were housed as two rabbits per cage and tagged according to the experimental groups/replicate for proper identification. There were six animals per group representing one control (A) and three treatment groups (B, $\mathrm{C}$ and $\mathrm{D}$ ) in a complete randomized design (CRD). The rabbits were weighed at the initiation of the experiment and subsequently at weekly intervals. Feed intakes were recorded daily. Experiment lasted for 42 days (six weeks). On the $43^{\text {rd }}$ day, two animals from each group were randomly selected and slaughtered and the following measurements were taken and analyses done; Live weight, carcass weight, meat, skin, head, thigh, limb, liver, spleen and stomach weight and length of intestine at the Animal Science Laboratory of Niger Delta University, Bayelsa State, Nigeria.

Data Collection and Analysis

The initial body weight of all replicates were noted and thereafter weekly body weight and feed consumption were recorded throughout the experiment. The rabbit's performance data on weight gain, feed intake, Feed Conversion Ratio (FCR) and survivability were calculated based on the records of body weight, feed intake and mortality respectively. Data on performance and carcass characteristics were subjected to Analysis of Variance (ANOVA) in SPSS Program Version 16 and were calculated as Standard Errors of the Mean (SEM), while Duncan's Multiple Range Test (DMRT) was used in assessing the significant differences among the treatment means. Significant was accepted at $0.5 \%$ level of probability.

\section{Results}

Proximate, Anti-nutritional and Essential Amino-acid Characteristics;

The proximate composition of Alchornea cordifolia leaf meal is presented in (Table 2) while the quantitative phytochemical analysis is presented in Table 3

Table 2. Proximate Composition of Alchornea cordifolia Leaf Meal*

\begin{tabular}{cc}
\hline Component & Composition (\%) \\
\hline Dry matter & 90.04 \\
Moisture content & 9.96 \\
Crude protein & 17.94 \\
Crude fibre & 16.84 \\
Ash & 11.38 \\
Energy & 3.37 \\
\hline
\end{tabular}

Alchornea leaf meal contain $17.94 \%$ Crude protein, $16.84 \%$ Crude fibre, $11.38 \%$ Ash and $3.37 \% \mathrm{kcal} / \mathrm{kg}$ Energy. 
The phytochemical composition (Table 3) shows the presence of Phytate, Oxalate, Saponins, Phenols, Cardiac glycoside and Hydrocyanic acid.

Table 3. Phytochemical composition of Alchornea leaf

\begin{tabular}{cc}
\hline Phytochemicals & Powder (\%) \\
\hline Phytate & 1.21 \\
Oxalate & 0.86 \\
Saponins & 2.04 \\
Phenols & 1.16 \\
Cardiac glycoside & 0.11 \\
Hydrocyanic acid & 22.30 \\
\hline
\end{tabular}

Table 4. Essentials Amino acids Compositions of Alchornea Leaf

\begin{tabular}{cc}
\hline Essential Amino acid & $\mathbf{\%}$ \\
\hline Histidine & 1.35 \\
Isoleucine & 2.48 \\
Leucine & 4.56 \\
Lysine & 3.84 \\
Methionine & 1.16 \\
Phenyl alanine & 2.04 \\
Threonine & 0.87 \\
Tryptophan & 1.03 \\
\hline
\end{tabular}

Growth Feed Intake and Feed Conversion

Addition of Alchornea cordifolia leaf meal to rabbit diet at 5,10 and $15 \%$ caused no significant difference $(\mathrm{P}>0.05)$ between treatments $\mathrm{A}$ to $\mathrm{C}$ in feed intake, but there was significant difference $(\mathrm{P}<0.05)$ between treatment $\mathrm{D}$ and the treatments $\mathrm{A}, \mathrm{B}$ and $\mathrm{C}$. Treatment $\mathrm{C}$ recorded the highest feed intake of $(131.94 \pm 7 \mathrm{~g})$ and treatment $\mathrm{D}$ had the lowest feed intake of $(94.44 \pm 10 \mathrm{~g})$. Results on weight gain showed no significant difference $(\mathrm{P}>0.05)$ across the treatment groups. Treatment $\mathrm{C}$ had the highest weight gain of $(1.36 \pm 04 \mathrm{~kg})$ and treatment $\mathrm{A}$ had the lowest weight gain of $(1.14 \pm 0.04 \mathrm{~kg})$. There was also no significance difference $(\mathrm{P}>0.05)$ in Feed Conversion Ratio (FCR) among the treatment group.

Table 5. Performance of Rabbits Fed Alchornea cordifolia Leaf Meal (ACLM)

\begin{tabular}{ccccc}
\hline Parameter & $\mathbf{A}(\mathbf{0 \%})$ & $\mathbf{B} \mathbf{( 5 \% )}$ & $\mathbf{C ~ ( 1 0 \% )}$ & $\mathbf{D}(\mathbf{1 5 \% )}$ \\
\hline $\begin{array}{c}\text { Initial Live } \\
\text { weight (kg) }\end{array}$ & $1.02 \pm 0.02$ & $1.12 \pm 0.03$ & $1.03 \pm 0.01$ & $1.03 \pm 0.03$ \\
$\begin{array}{c}\text { Final Live } \\
\text { weight (kg) }\end{array}$ & $1.48 \pm 0.03$ & $1.43 \pm 0.05$ & $1.49 \pm 0.02$ & $1.25 \pm 0.04$ \\
$\begin{array}{c}\text { Weight gain } \\
\text { (kg) }\end{array}$ & $0.46 \pm 0.04$ & $0.31 \pm 0.07$ & $0.46 \pm 0.04$ & $0.22 \pm 0.05$ \\
$\begin{array}{c}\text { Initial Feed } \\
\text { intake (kg) }\end{array}$ & $0.11 \pm 0.01$ & $0.11 \pm 0.04$ & $0.08 \pm 0.05$ & $0.06 \pm 0.03$ \\
$\begin{array}{c}\text { Final feed } \\
\text { intake (kg) }\end{array}$ & $0.119 \pm 0.03$ & $0.124 \pm 0.01$ & $0.155 \pm 0.02$ & $0.113 \pm 0.02$ \\
$\begin{array}{c}\text { Feed intake } \\
\text { (kg) }\end{array}$ & $0.09 \pm 10$ & $0.014 \pm 10$ & $0.075 \pm 7$ & $0.053 \pm 10$ \\
$\begin{array}{c}\text { FCR } \\
\text { Mortality } \\
(\%)\end{array}$ & 0.196 & 0.452 & 0.163 & 0.241 \\
\hline
\end{tabular}

Carcass Characteristics

Live weight is taken as weight before bleeding/slaughter. Carcass weight is taken as weight after bleeding/slaughter, meat weight is taken as the edible part of the rabbits i.e., after removal of the viscerals and skin along with the furs. Weight and measurement were collected from other parts/cuts of the rabbits as shown below in Table 6 .

Table 6. Carcass Characteristics of Rabbits Fed Alchornea Leaf Meal

\begin{tabular}{ccccc}
\hline Parameter & $\mathbf{0 . 0}$ & $\mathbf{5 . 0}$ & $\mathbf{1 0 . 0}$ & $\mathbf{1 5 . 0}$ \\
\hline Live & & & & \\
weight & $1.50 \pm 0.00$ & $1.65 \pm 0.07$ & $1.23 \pm 0.04$ & $0.95 \pm 0.07$ \\
(kg) & & & & \\
Carcass & & & & \\
weight & $0.70 \pm 0.35$ & $0.85 \pm 0.21$ & $0.68 \pm 0.04$ & $0.55 \pm 0.00$ \\
(kg) & & & & \\
Meat (kg) & $0.65 \pm 0.00$ & $0.70 \pm 0.25$ & $0.62 \pm 0.04$ & $0.40 \pm 0.00$ \\
Skin (g) & $138.0 \pm 7.07$ & $120.0 \pm 41.01$ & $87.5 \pm 13.44$ & $77.0 \pm 5.66$ \\
Head (g) & $144.5 \pm 10.61$ & $125.5 \pm 21.92$ & $111.0 \pm 1.41$ & $101.0 \pm 0.00$ \\
Thigh (g) & $92.0 \pm 9.89$ & $89.0 \pm 18.39$ & $87.0 \pm 0.00$ & $66.5 \pm 2.12$ \\
Limb (g) & $54.5 \pm 9.19$ & $49.0 \pm 12.73$ & $46.5 \pm 0.71$ & $34.5 \pm 2.12$ \\
Back $(\mathrm{g})$ & $0.30 \pm 0.07$ & $0.23 \pm 0.04$ & $0.21 \pm 0.01$ & $0.20 \pm 0.01$ \\
Intestine & $4.27 \pm 0.18$ & $4.27 \pm 0.67$ & $3.70 \pm 0.42$ & $2.55 \pm 0.78$ \\
(g) & & & & \\
Liver (g) & $42.50 \pm 2.12$ & $34.00 \pm 4.24$ & $34.00 \pm 0.00$ & $24.00 \pm 4.24$ \\
Spleen (g) & $0.50 \pm 0.00$ & $0.25 \pm 0.07$ & $0.30 \pm 0.00$ & $0.25 \pm 0.07$ \\
Stomach & $96.50 \pm 23.34$ & $92.00 \pm 5.66$ & $66.50 \pm 10.61$ & $53.00 \pm 4.24$ \\
(g) & & & & \\
\hline
\end{tabular}

\section{Discussion}

The proximate analysis of the treatment diet fed to the rabbits was as follows: Crude Protein (CP) and Metabolizable Energy (ME) of $18.0 \%$ and $2.59 \% \mathrm{kcal} / \mathrm{kg}$. It offered the normal nutrition required for maximum performance. Little is known about the proximate composition and anti-nutritional factors in Alchornea cordifolia leaf or the effects of processing procedures such as air and sundrying on the compounds. This remains for future research. But based on chemical analysis ACLM is a valuable source of nutrient for monogastrics such as pig, poultry and rabbit. However no systematic research is known to have been done in the nutritional quality and phytochemical properties of Alchornea cordifolia leaves for any monogastric species. The significant difference $(\mathrm{P}<0.05)$ in feed intake of the rabbits between 15\% ACLM and the rest of the treatments is an indication that inclusion levels of $15 \%$ and above of ACLM in rabbit diet may decrease feed intake while inclusion levels between $5-10 \%$ had better performance in feed intake and this is probably due to the lower inclusion levels compared to treatment $\mathrm{D}$, also the caecum of the rabbits can digest highly fibrous plant materials. This agrees with the findings of Aduku and Olukosi, [11], who stated that rabbits are pseudo-ruminants and as such are able to utilize forages as well as concentrates. There was no significant difference $(\mathrm{P}>0.05)$ in weight gain across the treatment groups. Treatment with 10\% ACLM recorded the highest weight gain and there was also no significant difference $(\mathrm{P}>0.05)$ in feed conversion ratio among the Treatment groups. There was significant difference $(\mathrm{P}<0.05)$ observed in the values of parameters obtained in live weight and head weigh whereas skin, thigh, carcass, meat, limb, and back weights were similar across the treatment diets. No treatment effect $(\mathrm{P}<0.05)$ was observed in some carcass 
parameters such as shoulder, tail, kidney, heart, lungs and caecum, while on the other hand significant difference $(\mathrm{P}<0.05)$ were noticed on other carcass parameters; stomach, spleen, liver and intestine decline with increasing levels of ACLM in the diet which may be as a result of some antinutritional factors in Alchornea cordifolia which affects the rabbits in terms of final product (carcass). This agrees with the findings of Bangbose et. al, [12] who stated that high inclusion of Tigernut Meal (TNM) in the diet of weaner rabbits decrease protein percentage in carcass.

\section{Conclusion}

This study concludes that the use of ACLM may be recommended as protein source for rabbits at $5-10 \%$ inclusion levels in the diet. Additional work to investigate the economic significance of using ACLM as rabbit nonconventional feed supplement/feed additive compared to other feedstuff is on- going in our research laboratory. Further studies will be carried out to see if any health effects can be observed due to ACLM feeding to detect quality of rabbit meat fed this ACLM.

\section{Acknowledgement}

The author wishes to thank Sylvester C. Izah and Tariwari C.N Angaye for the editorial work.

\section{References}

[1] S. A. Majgandi, and I. F. Ngang, Performance of rabbit fed varying levels of calabash seed cake. Journal of Agriculture and Environment 2002, pp. $201-208$.

[2] S. K. Das, and K. M. Bujarbaru, Carcass Trait of Rabbits, Organoloeptic properties and consumption pattern of rabbit meat in the North Eastern Hill Region of India. PanAmerican Rabbit Sci. Newsletter 2005, pp. 39-43.

[3] F. Lebas, P. Coudert, R. Rouvier and H. de Rochambeau, The Rabbit-Husbandary, Health and Production. FAO, Rome, 1986.

[4] J. Adrian, G. Legrand and R. Frangne, Dictionaire de biochimie elmimentaire et de nutrition. Paris, France. Technique et Documentation, 1981.

[5] O.M. Daudu M,Orunmuyi and G.E. Joktham, Use of non conventional feeds: potentials and constraints for rabbit production in Nigeria. Proceedings of the 34th Annual conference of the Nigerian Society for Animal Production (NSAP).March 15th -18th , University of Uyo, Uyo,. Nigeria, (2009) page 198-201

[6] S.N. Wekhe, and C. O Njoku, Preliminary investigations of the effect of Alchoria cordijolia on weight gain and organ size of broilers. Proc. 5th annual conf. of ASAN, Sept. 1923, 2000. Port Harcourt. pp. 56-58.

[7] B. Oliver, Medical Plant in Nigeria. Nigerian College of Arts. Science and Technology Vol. 1, 1960, pp. 138.

[8] B. Oliver - Bever. Medical Plants in Tropical West Africa. Cambridge University Press, London. 1986, pp. 115.

[9] P. C. N. Alikwe, and O. J. Owen, Evaluation Of The Chemical And Phytochemical Constituents Of Alchornea Cordifolia Leaf Meal As Potential Feed For Monogastric Livestock African Journal of Food Agriculture Nutrition and Development 2013, in press.

[10] A. O. Aduku and J. O. Olukosi,Rabbit Management in the Tropics Living Books Series. GU Publications, Abuja, Nigeria. Vol. 1, 1990, pp. 33-34.

[11] A. M. Bamgbose, M. Abimbola, W. A Olayemi, A. O. Osofowora, A. O. Oso, and O. T. Ojo, Performance of weaner rabbits fed supplemented Tridax procumbens. Proc. $7^{\text {th }}$ Anun. Conf. Anim. Sci. Ass. of Nig. (ASAN). In: Fanimo, OA (eds). September 16-19, 2002, University of Agriculture, Abeokuta. Nigeria. 